\title{
SILA KE-EMPAT PANCASILA DAN IKLIM DEMOKRASI INDONESIA SAAT INI
}

\author{
Efendi Susanto \\ Fakultas Hukum Universitas Jenderal Soedirman \\ Jl. Prof. Dr. H.R. Boenyamin No. 708, Grendeng, Purwokerto \\ fendipratama1982@gmail.com
}

\begin{abstract}
This article discusses about local election in Indonesia from the perspective of the fourth principle of Pancasila. Restoring the democratic climate in Indonesia based on Pancasila is an important matter of national concern. The government in carrying out democracy should be consistent with what has been agreed in the Pancasila. Indonesia has agreed that Pancasila is placed as an agreement, and a value system that must be used as a guideline for developing and achieving the country's goals. Elections should be held by people's representative body as a manifestation of the fourth precepts. Pancasila which prioritizes the principle of deliberation to reach consensus through its representatives and representative bodies in fighting for the people's mandate. Therefore, it is necessary to think about local head elections through people's representatives body in accordance with the mandate of Pancasila.
\end{abstract}

Keywords: Elections; Pancasila; Democracy; People's Representative Body.

\begin{abstract}
Abstrak
Artikel ini membahas mengenai pemilihan kepala daerah di Indonesia dari perspektif sila keempat Pancasila. Mengembalikan iklim demokrasi di Indonesia berdasarkan Pancasila menjadi hal yang penting menjadi perhatian bangsa. Pemerintah dalam menjalankan demokrasi hendaknya konsisten dengan apa yang sudah disepakati dalam Pancasila. Indonesia sudah menyepakati bahwa Pancasila sebagai konsensus luhur dan satu kesatuan nilai yang harus digunakan sebagai pedoman untuk mencapai tujuan negara. Pemilu hendaknya diselenggarakan oleh lembaga perwakilan rakyat sebagai perwujudan amanat sila ke-empat. Pancasila yang mengedepankan prinsip musyawarah untuk mufakat melalui wakil-wakilnya dan badan-badan perwakilan dalam memperjuangkan mandat rakyat sebagai konsep perwakilan yang diamanatkan oleh Pancasila. Oleh karena itu, perlu dipikirkan pemilihan kepala daerah melalui badan perwakilan rakyat, sesuai dengan amanat dari Pancasila.
\end{abstract}

Kata Kunci: Pemilu; Pancasila; Demokrasi; Lembaga Perwakilan Rakyat.

\section{A. Pendahuluan}

Setiap negara mempunyai ideologi yang berbeda-beda, termasuk Indonesia. Indonesia menciptakan ideologinya sendiri sesuai dengan corak dari masyarakatnya, yaitu ideologi berdasarkan Pancasila. Pancasila sebagai ideologi memiliki peran penting untuk membangun bangsa dan negara pada kehidupan praktik rakyat
Indonesia. Pancasila memiliki kekebalan dengan tidak dapat diintervensi oleh pengaruh ideologi lain (Mulyono \& Fatoni, 2019).

Bangsa dan negara Indonesia adalah suatu bangsa yang lahir "atas berkat Rahmat Allah Yang Maha Kuasa", dan pengakuan ini secara resmi dituangkan dalam dokumen tertinggi Pembukaan UUD 1945, dan Ketuhanan Yang Maha Esa dimasukkan 
dalam Bab XI tentang Agama Pasal 29 ayat (1) UUD NRI 1945. Pernyataan tersebut membawa pengertian dan pengakuan bahwa keberadaan dan asal usul bangsa Indonesia adalah karena campur tangan dan kehendak Allah Yang Maha Kuasa bukan dihasilkan oleh suatu perjanjian masyarakat dari individu-individu yang bebas seperti konsep negara liberal. Bagi bangsa Indonesia ada hubungan yang erat antara negara dan agama yang bertumpu pada Ketuhanan Yang Maha Esa yang merupakan sila pertama dari Pancasila, dan dengan demikian bangsa Indonesia memiliki perangkat hukum yang luhur sebagai landasan kehidupan berbangsa dan bernegara yaitu Pancasila dan UUD 1945 (Wahyuningsih, 2014).

Pancasila sebagai ideologi bangsa yang sudah disepakati dan bersifat final selalu menjadi bahan yang menarik untuk dibicarakan hingga saat ini, khususnya berkaitan dengan implementasi sila-sila Pancasila dalam praktik kehidupan manusia dan bernegara. Pancasila dijadikan sebagai pijakan kehidupan bernegara untuk mencapai kesejahteraan yang adil, makmur dan sentosa sebagaimana yang menjadi amanat dari Alinea IV Pembukaan UUD 1945. Namun, keberadaan Pancasila selalu menjadi kambing hitam atas kondisi bangsa yang belum tertib dan sejahtera seperti kondisi saat ini. Keberadaan Pancasila dianggap tidak mampu memberikan kesejahteraan kepada manusia Indonesia. Pancasila sebagai ideologi dianggap tidak bisa memenuhi harapan dari negara untuk mewujudkan tujuan bernegara dan berbangsa. Pancasila diragukan tidak bisa digunakan untuk menghadapi tantangan globalisasi di tengah tuntutan yang begitu besarnya.

Perkembangan mendeskreditkan Pancasila menjadi penanggungjawab kondisi negara yang masih jauh dari kesejahteraan. Negara-negara di dunia yang berideologi liberal maupun sosialis justru dianggap lebih mampu menghadapi perubahan kehidupan dan dapat tampil dalam pergaulan dunia dibandingkan negara Indonesia yang notabene memiliki ideologi lebih baik dibandingkan negara-negara di dunia. Hal inilah yang kemudian seringkali Pancasila disalahkan sebagai penyebab negara Indonesia belum mengalami kemajuan yang pesat.

Mengetahui manfaat Pancasila hendaknya mengupas lebih ke dalam lagi, hingga muncul pertanyaan mendasar mengenai bagaimana implementasi nilainilai Pancasila sebagai dasar negara dalam kehidupan demokrasi di Indonesia saat ini? Apakah nilai-nilai Pancasila sudah terimplementasi dengan baik dan konsisten? Dalam konteks ini, penulis ingin membatasi permasalahan yang akan dikaji, yaitu perkembangan demokrasi yang berkaitan dengan pemilihan kepala daerah secara langsung, sebagaimana yang diatur dalam UUD NRI Tahun 1945 Pasal 22E dan Pasal 18 ayat (4), apakah sudah sesuai dengan nilai-nilai Pancasila atau belum, khususnya amanat dari sila ke-empat Pancasila.

Setelah runtuhnya rezim orde baru dan bergulirnya rezim reformasi terjadi perubahan yang sangat besar dalam sistem ketatanegaraan Indonesia, salah satunya mengenai sistem demokrasi dari demokrasi tidak langsung menjadi demokrasi langsung. Perubahan ini membawa implikasi pada mekanisme pengambilan keputusan dalam pemilihan umum di Indonesia. Jika sebelumnya pemilihan umum dilakukan oleh lembaga perwakilan, sekarang menggunakan sistem pemilihan umum langsung di mana rakyat langsung memilih. Artinya, saat ini digunakan sistem pemungutan suara yang konsekuensinya suara terbanyak itulah yang menang.

Demokrasi yang merupakan pencerminan Pancasila dapat dilihat dari penyelenggaraan Pemilu sebagai pilihan cara berdemokrasi saat ini. Hal ini berangkat dari beberapa negara yang menganggap bahwa negara yang demokratis adalah negara yang dapat menjadi sarana terpilihnya para wakil rakyat, di mana hal ini menggambarkan suasana demokrasi itu sendiri (dari rakyat, oleh rakyat dan untuk rakyat). Tentunya parameter yang digunakan 
oleh Indonesia adalah Pancasila, tepatnya dalam implementasi nilai Pancasila pada sila ke-empat yang berbunyi "Kerakyatan yang dipimpin oleh hikmat kebijaksanaan dalam permusyawaratan/perwakilan". Hal inilah yang menjadi alasan penulis untuk melakukan kajian mengenai hal tersebut. Oleh karena itu, dalam penulisan ini akan mengkaji dan menganalisis apakah pemilihan kepala daerah di Indonesia saat ini sudah sesuai dengan amanat dari sila keempat Pancasila.

Penelitian tentang sistem pemilihan kepala daerah telah dilakukan sebelumnya, seperti Nopyandri dengan judul "Pemilihan Kepala Daerah Yang Demokratis Dalam Perspektif UUD 1945". Penelitian ini berfokus pada politik hukum pemilihan kepala daerah dengan menampilkan kelebihan dan kekurangan pemilihan kepala daerah yang sekarang ini dilakukan. Penelitian juga dilakukan oleh $\mathrm{M}$. Aminullah dengan judul "Membangun Politik Hukum Pemilihan Kepala Daerah Yang Demokratis Di Indonesia". Penelitian ini juga melihat bagaimana politik hukum pemilihan kepala daerah secara demokratis dengan mengkaji kelemahan UndangUndang Nomor 8 Tahun 2015. Penelitian dilakukan oleh Wahyu Widodo dengan judul "Pelaksanaan Pilkada Berdasarkan Asas Demokrasi dan Nilai-Nilai Pancasila". Penelitian ini berfokus pada reduksi nilai dalam pelaksanaan pemilihan kepala daerah saat ini karena pelaksanaan Undang-Undang tentang Pemilihan Kepala Daerah tidak dijiwai oleh nilai-nilai Pancasila.

Berdasarkan penelitian sebelumnya, maka fokus penulisan ini yang berbeda dengan penelitian sebelumnya adalah mengenai hakikat dan legitimasi pemilihan kepala daerah secara langsung sebagaimana yang dilakukan Indonesia saat ini, berdasarkan amanat dari sila ke-empat Pancasila serta bagaimana kedudukan Pancasila sebagai sumber dari segala sumber hukum dalam pelaksanaan pemilihan kepala daerah, sehingga diharapkan menggunakan model perwakilan dalam pemilihan kepala daerah ke depannya sesuai dengan nilai-nilai Pancasila.

\section{B. Pembahasan}

\section{Pemilihan Umum dan Demokrasi}

Ketika membicarakan Pemilu, maka harus berangkat dari uraian mengenai apa arti penting dari konsep demokrasi itu. Pemilu dan demokrasi adalah dua hal yang mempunyai hubungan erat dan pengkajiannya tidak dapat dipisahkan. Menurut Arbi Sanit (Sanit, 2009), Pemilu merupakan institusi yang mengejawantahkan demokrasi. Pemilu adalah suatu kegiatan yang dapat menjadi sarana untuk menyalurkan hak-hak warga negara yang sangat prinsip (Asshiddiqie, 2013). Keharusan pemerintah menjamin penyelenggaraan kedaulatan rakyat tersebut. UUD 1945 telah mengamanatkan bahwa negara harus memenuhi hak-hak warga negara, yaitu hak politik warga negara, khususnya hak pilih dan memilih setiap Warga Negara Indonesia. Artinya, hal ini menegaskan bahwa segala bentuk peraturan perundang-undangan yang mengatur tentang Pemilu, seharusnya membuka ruang yang seluas-luasnya bagi setiap warga negara untuk bisa menggunakan hak pilihnya dalam Pemilu.

Dalam kerangka negara demokrasi, pelaksanaan Pemilu merupakan momentum yang sangat penting bagi pembentukan pemerintahan dan penyelenggaraan negara periode berikutnya. Pemilu merupakan mekanisme bagi rakyat untuk memilih para wakil juga dapat dilihat sebagai proses evaluasi dan pembentukan kembali kontrak sosial. Peran sentral Pemilu ini terlihat sebagai perwujudan kedaulatan rakyat, maka dalam konstitusi negara UUD 1945 Pasal 1 ayat (2) memberikan jaminan bahwa Pemilu adalah salah satunya cara untuk mewujudkan kedaulatan rakyat. Artinya, Pemilu merupakan pranata wajib dalam pelaksanaan kedaulatan rakyat dan konstitusi memberikan arah dan mengatur tentang prinsip-prinsip dasar Pemilu yang akan dilaksanakan (Soerya, 2013). 
Pemilu merupakan sebuah sarana kompetisi untuk pengisian jabatan-jabatan politik yang didasarkan pada pemilihan oleh warga negara yang telah memenuhi syarat untuk memilih dalam pemilihan umum (Sarbaini, 2015). Lahirnya pemilu berasal dari konsep dan gagasan besar demokrasi dari John Lock dan Rousseau, terjaminnya keadilan, kebebasan dan kesetaraan bagi rakyat. Terdapat nilai-nilai dalam demokrasi yang selalu dijalankan oleh warga negara dan organ-organ negara, baik di lingkungan legislatif, eksekutif maupun yudikatif. Nilainilai tersebut adalah nilai-nilai keterlibatan/partisipatif dan nilai kedaulatan oleh rakyat (Bachtiar, 2014). Pemilihan umum menjadi sebuah peluang bagi rakyat untuk menyalurkan kehendak politiknya dan memilih orang-orang yang harus menjalankan kebijaksanaan politik rakyat secara serentak oleh seluruh warga negara (Azed, 1987). Pemilu demokratis bukan saja menghajatkan proses penyelenggaraannya yang free and fair, tetapi juga membutuhkan sistem Pemilu yang benar-benar memberikan tempat utama bagi suara atau pilihan rakyat (Ismatullah \& Gatara, 2007).

Mekanisme utama dalam membentuk dan menyelenggarakan pemerintahan adalah pemilu. Pemilu dipandang sebagai sarana paling nyata dari kedaulatan rakyat. Berdasarkan hal tersebut, maka sistem penyelenggaraan pemilu selalu dijadikan perhatian utama dari pemerintahan agar prinsip dari, oleh, dan untuk rakyat benarbenar dapat terwujud dengan menata sistem penyelenggaraan pemilu, khususnya pada kualitas penyelenggaraannya (Hardiyanto $\mathrm{dkk}, 2016$ ).

Di dalam negara yang memiliki masyarakat yang majemuk (plural), kedaulatan rakyat tidak dapat dilakukan secara sendiri, tetapi memerlukan perwakilan. Pelaksanaan kedaulatan rakyat semacam ini dinamakan sistem demokrasi perwakilan atau demokrasi tidak langsung. Pada sistem demokrasi perwakilan, kedaulatan rakyat dijalankan oleh wakil rakyat yang ada di lembaga perwakilan. Para wakil rakyat ini diberikan mandat oleh rakyat untuk bertindak dan menentukan jalannya pemerintahan, baik dalam jangka waktu panjang maupun pendek. Para wakil rakyat inilah yang akan menampung aspirasi rakyat guna mencapai tujuan yang dikehendaki oleh rakyat sebagai pemegang kekuasaan tertinggi di dalam negara.

\section{Pokok-Pokok yang Terkandung dalam Sila ke-empat Pancasila}

Pancasila terdiri atas lima sila yang pada hakikatnya merupakan suatu sistem. Sebagai suatu sistem, Pancasila terdiri atas sila-sila yang memiliki fungsi masingmasing namun merupakan satu kesatuan utuh yang tidak terpisahkan demi mencapai tujuan negara berdasarkan Pancasila dan konstitusi (Juliardi, 2015). Dalam konteks permasalahan dalam penulisan ini, sangat berkaitan dengan sila ke-empat Pancasila.

Sila ke-empat Pancasila menyebutkan "Kerakyatan yang dipimpin oleh hikmat kebijaksanaan dalam permusyawaratan/perwakilan". Kerakyatan adalah kekuasaan tertinggi berada di tangan rakyat. Hikmat kebijaksanaan artinya bahwa menggunakan pikiran yang sehat dan dilaksanakan dengan jujur dan bertanggung jawab sesuai hati nurani, dengan selalu mengutamakan kepentingan rakyat, persatuan dan kesatuan bangsa. Permusyawaratan artinya menggunakan musyawarah untuk mufakat apabila merumuskan dan memutuskan suatu hal berdasarkan kehendak rakyat. Perwakilan berarti dalam hal melaksanakan kehendak rakyat dalam kehidupan bernegara dilakukan melalui badan perwakilan rakyat.

Bila dicermati, arti dan makna Sila keempat sebagai berikut: a) Kerakyatan yang mencerminkan demokrasi, adalah pemerintahan dari, oleh, dan untuk rakyat; b) Permusyawaratan berarti memutuskan sesuatu secara bersama-sama untuk mencapai kesepakatan yang bulat melalui jalan kebijaksanaan; c) Menjalankan keputusan dengan penuh tanggung jawab dan jujur. Dengan memutuskan suatu hal secara bulat, maka haruslah adanya kejujuran bersama-sama pula sebagai konsekuensinya. Permusyawaratan sebagai identitas; dan, d) Mengandung asas 
kerakyatan dan musyawarah untuk mufakat. Asas kerakyatan dalam hal ini adalah adanya rasa cinta kepada rakyat dan ingin memperjuangkan cita-cita rakyat. Asas musyawarah untuk mufakat, berarti aspirasi rakyat diperhatikan dan dihargai serta diperjuangkan melalui majelis permusyawaratan, menghargai perbedaan, mengutamakan kepentingan rakyat, bangsa dan negara (Yusdiyanto, 2016).

Berdasarkan sila ke-empat Pancasila, negara berkedaulatan rakyat menjadi landasan absolut dalam kehidupan politik negara Indonesia. Artinya, bahwa sifat demokrasi tidak dapat diubah atau bahkan dihilangkan dalam politik negara. Demokrasi menjadi suatu hal yang mutlak. Namun, dalam sila ke-empat mengandung pula sila-sila yang lain yang menjadi konsekuensi Pancasila sebagai suatu sistem. Kerakyatan dalam konteks sila ke-empat ini adalah kerakyatan yang berke-Tuhanan Yang Maha Esa, Yang berkemanusiaan adil dan beradab, yang berpersatuan Indonesia dan yang berkeadilan sosial bagi seluruh rakyat Indonesia. Artinya, jalannya demokrasi di Indonesia adalah demokrasi yang disinari oleh sinar-sinar Ketuhanan, yang dijalankan secara beradab dan berkemanusiaan dalam persatuan Indonesia dan untuk keadilan sosial bagi seluruh rakyat Indonesia.

Sila ke-empat mengharuskan negara untuk menjamin bahwa rakyat dalam menjalankan kedaulatannya benar-benar secara demokratis dan tanpa diskriminasi melalui wakil-wakilnya. Negara wajib menampung dan memperjuangkan aspirasi dan kepentingan dari seluruh rakyat yang memiliki kedaulatan tersebut. Pemimpin harus memiliki akal yang sehat, rasional, berhati nurani, arif dan bijaksana, jujur serta adil sehingga dapat menjadi pemimpin yang mumpuni dan berintegritas melalui bentuk dan arahan permusyawaratan/perwakilan.

Sila ke-empat ini mengamanatkan bahwa dalam mengatasi tiap-tiap permasalahan sebaiknya dengan mengutamakan musyawarah mufakat sebagai prinsip dari demokrasi, khususnya dalam konteks pengambilan keputusan negara yang diwakili oleh perwakilan rakyat yaitu oleh lembaga DPR dan DPD. Lembaga perwakilan rakyat dalam mengambil kebijakan perlu mendahulukan kepentingan rakyat di atas kepentingan pribadi. Jangan sampai pemimpin hanya mengutamakan kepentingan kelompok/pribadinya saja (Pinilih \& Hikmah, 2018).

\section{Pemilihan Kepala Daerah dalam Perspektif Sila ke-empat Pancasila}

Indonesia sebagai negara hukum, maka segala sesuatu harus didasarkan kepada hukum baik tertulis maupun hukum tidak tertulis. Demikian halnya dengan sistem ketatanegaraan sudah seharusnya dilaksanakan sesuai dengan hukum (rule of law). UUD NRI Tahun 1945 sebagai hukum dasar dan Pancasila menjadi sumber dari segala sumber hukum di Indonesia. UUD NRI Tahun 1945 merupakan bentuk pengejawantahan dari nilai-nilai yang ada dalam sila Pancasila, artinya segala pengaturan yang terdapat dalam UUD NRI Tahun 1945 dan peraturan di bawah UUD NRI Tahun 1945 tidak boleh bertentangan dengan nilai-nilai Pancasila. Begitu juga pemilihan umum, pemilihan umum diletakkan pada bab khusus dalam UUD NRI Tahun 1945 karena pemilu dianggap sesuatu yang sangat penting karena merupakan sarana kedaulatan rakyat yang menjadi prinsip penyelenggaraan negara (Al Hidayat, 2018).

Pemilu telah diatur dalam Pasal 22E UUD NRI Tahun 1945. Pasal 22E mengamanatkan bahwa pemilu dilaksanakan dalam setiap lima tahun secara langsung, umum, bebas, rahasia, jujur, dan adil. Pemilu diselenggarakan oleh Komisi Pemilihan Umum (KPU) yang bersifat tetap dan mandiri, baik KPU di tingkat nasional maupun daerah. Dalam konteks penulisan ini adalah pemilihan kepala daerah. Jika dikaji secara filosofis, menurut penulis, ketentuan "dipilih secara langsung oleh rakyat" bertentangan dengan esensi sila ke 4 Pancasila yang menentukan "kerakyatan dipimpin oleh hikmat kebijaksanaan dalam permusyawaratan perwakilan". Hal ini 
menunjukkan sila ke-empat Pancasila mengedepankan prinsip musyawarah untuk mufakat melalui wakil-wakilnya dalam memperjuangkan mandat rakyat. Artinya, terkait pemilihan kepala daerah seharusnya dilakukan oleh lembaga perwakilan rakyat resmi yang merupakan representasi dari rakyat Indonesia.

Jika dikaji berdasarkan arti dari "musyawarah mufakat" dalam pengambilan keputusan, pelaksanaan pemilihan kepala daerah yang dilakukan secara langsung tidak sesuai dengan nilai-nilai yang terdapat dalam demokrasi Pancasila yang mengedepankan musyawarah mufakat. Hal ini dapat dimaknai bahwa terdapat ketidaksesuaian antara aturan-aturan normatif terkait pemilihan kepala daerah, baik yang terdapat dalam UUD 1945 maupun peraturan perundang-undangan yang lebih rendah dengan tataran filosofisnya yaitu Pancasila sebagai dasar negara. Dalam praksisnya, jika pemilihan kepala daerah dilakukan oleh lembaga perwakilan rakyat akan lebih efektif dan efisien mengingat luasnya wilayah Indonesia sehingga akan mempersingkat waktu dan biaya dapat ditekan.

Pemilihan kepala daerah melalui perwakilan sebenarnya sudah memiliki legitimasi dalam konstitusi Indonesia. Pasal 18 ayat (4) UUD NRI Tahun 1945 menyatakan bahwa Gubernur, Bupati dan Walikota dipilih secara demokratis. Kata demokratis ini mengacu pada demokrasi Pancasila. Artinya, demokrasi Pancasila ini mengutamakan musyawarah mufakat tanpa oposisi. Demokrasi Pancasila menginginkan bahwa kompetisi berbagai cara dan ide untuk penyelesaian masalah bukan berdasarkan suara terbanyak, tetapi dengan cara keterwakilan (Nugraha \& Mulyandari, 2016). Pemilihan kepala daerah pada awalnya dilakukan melalui keterwakilan oleh DPRD, yang kemudian mekanisme ini berganti kembali secara langsung oleh rakyat. Baik pemilihan secara langsung maupun melalui perwakilan pada dasarnya tidak bertentangan dengan konstitusi dan Pancasila sebagai dasar negara. Bedanya, pemilihan secara langsung menggunakan demokrasi secara murni yang dilakukan oleh rakyat, sedangkan pemilihan melalui keterwakilan merupakan perwujudan dari pelaksanaan demokrasi Pancasila. Anggota DPR/DPRD merupakan perwujudan rakyat Indonesia, dengan demikian pemilihan melalui wakil rakyat tidak bertentangan dengan demokrasi Pancasila (Wawan S., 2015).

Hal ini menggambarkan bahwa rakyat sebagai pemegang kekuasaan tertinggi dalam negara dipimpin oleh seorang yang benar-benar mencerminkan hikmat dan bijaksana serta mengedepankan permusyawaratan di dalam pengambilan setiap keputusan yang dilandaskan atas kemanfaatan bagi seluruh rakyat Indonesia tanpa terkecuali melihat suku, ras, agama maupun golongan semata. Pemilu yang demikian merupakan wujud dari Pancasila sila ke-empat yang merupakan bentuk demokrasi yang berasaskan nilai-nilai Pancasila. Oleh karena itu, perlu disiapkan sebuah mekanisme untuk meminimalisir hal tersebut, juga perlu disiapkan kader-kader anggota parlemen yang jujur, amanah, dan memiliki kredibilitas yang tinggi. Menurut penulis, mekanisme yang dapat dilakukan untuk memilih kepala daerah melalui DPRD sebagai lembaga perwakilan dari rakyat daerah. Namun, hal ini sebaiknya tidak terlepas dari pengawasan rakyat. Rakyat diberikan hak pula untuk mengawasi mekanisme tersebut. Mekanisme pemilihan melalui DPRD tetap harus dalam konteks negara demokrasi yang berdasarkan hukum dan Pancasila.

Selain itu, apabila dikaitkan dengan kondisi politik di negara Indonesia saat ini, pemilihan kepala daerah secara langsung memiliki sejumlah kelemahan, sehingga tidak menguntungkan bagi demokrasi Indonesia. Kelemahan-kelemahan yang sering kali muncul dari pemilihan kepala daerah secara langsung menurut penulis, antara lain:

a. Rawan terjadinya konflik horizontal.

Rawan terjadi konflik di sini adalah konflik antar kubu peserta pemilu. 
Semakin bertambahnya peserta pemilihan, maka akan semakin banyak pesaing. Masing-masing peserta juga memiliki kubu-kubunya. Data dari Kementerian Dalam Negeri sampai dengan tahun 2013, terdapat 50 korban jiwa kerusuhan akibat pemilihan kepala daerah yang tentunya disebabkan karena ketidakpuasan dari kubu peserta terhadap hasil pemilihan kepala daerah di seluruh Indonesia, bahkan di tahun 2011 timbul korban jiwa sebanyak 57 orang akibat konflik antar kubu pada pemilihan kepala daerah di Kabupaten Puncak Papua (Insiyah, Nugraha, \& Danmadiyah, 2019). Tingginya korban jiwa ini menggambarkan bahwa pemilihan secara langsung sangat rawan terjadinya konflik horizontal. Hal ini tentunya tidak sesuai dengan tujuan dari prinsip-prinsip demokrasi yang justru melanggar hak hidup dari masyarakat. Dengan pemilihan melalui DPRD, maka besar kemungkinan dapat menekan terjadinya konflik horizontal, namun pemilihan oleh DPRD ini tentunya tetap harus ada pengawasan dari publik pula.

b. Tingginya biaya pengadaan pemilihan. Selain rawan terjadi konflik antar kubu, tingginya anggaran penyelanggaraan pemilihan secara langsung juga ikut andil. Anggaran yang harus dikeluarkan cukup besar oleh pemerintah daerah, mulai dari proses pemuthakiran data pemilih, pengadaan, distribusi logistik, dan sebagainya. Belum lagi jika dilakukan pemilihan putaran kedua yang tentunya biaya akan bertambah. Hal ini bisa ditekan biayanya jika dilakukan pemilihan melalui DPRD karena akan meminimalisasi proses pemilihan.

c. Praktik politik uang (money politic). Terjadinya politik uang umumnya pada proses penjaringan dan penetapan calon. Pelarangan praktik politik uang ini sudah diatur di Undang-Undang Nomor 8 Tahun 2012 tentang Pemilihan Umum Anggota DPR, DPD dan DPRD dan Undang-Undang Nomor 32 Tahun 2008 tentang Pemberhentian Kepala Daerah. Namun, kedua undang-undang tersebut hanya mengatur sanksi pidana terhadap pengurus partai politik, calon peserta, juru kampanye, individu, dan organisasi yang ditunjuk sebagai peserta pemilu, tetapi belum mengatur sanksi pidana atas tindakan politik uang tersebut (Firdaus, 2020).

Melihat pula bahwa penyelenggaran pemilihan secara langsung menimbulkan banyak kelemahan dalam praktiknya, maka perlu dipikirkan untuk kembali pada konsep demokrasi sebagaimana yang diamanatkan oleh Pancasila, yaitu pemilihan kepala daerah melalui badan perwakilan rakyat, dalam hal ini adalah DPRD.

Berdasarkan

kondisi-kondisi sebagaimana di atas, dapat disimpulkan pada saat ini kehadiran Pancasila sebagai dasar negara Indonesia telah bergeser fungsi dan kedudukannya. Hal ini disebabkan kurangnya kesadaran para penyelenggara pemerintahan terhadap esensi dasar Negara Indonesia yaitu Pancasila. Demokrasi yang dijalankan oleh Indonesia selama ini tidak konsisten dengan apa yang sudah disepakati bersama dalam Pancasila. Demokrasi di Indonesia bukanlah demokrasi sebagaimana yang dijalankan oleh negara barat, tetapi demokrasi yang Indonesia jalankan adalah demokrasi yang berlandaskan serta berasaskan sila-sila Pancasila, yang berasal dari corak masyarakat Indonesia itu sendiri.

Prinsip pemilu berdasarkan Pancasila ini justru menjadi pembeda dari pemilu yang diselenggarakan oleh negara lain, di mana tidak hanya melihat kuantitas belaka, tetapi juga mengedepankan kualitas figur/calon yang mempunyai jiwa dan pemikiran yang bijaksana dan kehikmatan untuk kebaikan bersama. Terselenggaranya pemilihan umum yang berkualitas dibutuhkan peran partai politik untuk mendidik para kadernya menjadi kader-kader yang mempunyai integritas dan kemampuan serta dedikasi kepada bangsa dan negara, sehingga terwujud serta tercapai tujuan diselenggarakannya pesta kedaulatan rakyat (Nahuddin, 2017). 
Demokrasi berdasarkan Pancasila sebagaimana yang menjadi kesepakatan bersama bangsa Indonesia justru dilaksanakan oleh Amerika yang merupakan sebuah negara liberal dan telah berangsur lama menerapkan demokrasi tetapi masih dalam proses ke arah demokrasi yang lebih baik. Artinya, saat ini sistem demokrasi Amerika masih memerlukan waktu yang cukup panjang untuk mewujudkan proses demokrasi yang baik. Namun, demokratisasi yang dijalankan oleh Amerika justru telah lebih banyak menghasilkan perkembangan yang pesat bagi negaranya. Bahkan, Negara Amerika telah menjadi kiblat demokrasi, yang secara tidak disadari telah menerapkan Pancasila dalam menjalankan aktivitas demokrasinya.

Hal ini dapat dilihat pada model pemilu di Amerika tidak menggunakan sistem one man one vote seperti di Indonesia, di mana dalam sistem Amerika setiap orang tidak memilih secara langsung tetapi diwakilkan oleh orang-orang yang dianggap dapat mewakilkan aspirasi kelompoknya. Sistem yang demikian justru mencerminkan perwakilan sebagaimana amanat dari sila ke4 Pancasila. Keadaan inilah yang kemudian menjadi suatu alasan untuk kembali merenungkan serta mengkaji secara komprehensif berkaitan dengan penyelenggaran pemilihan umum di Indonesia. Merekonseptualisasi pandangan Pancasila yang menjadi satu-satunya pilihan cara untuk mengimplementasikan demokrasi langsung hingga saat ini, sehingga atas kondisi-kondisi tersebut di atas dapat bertujuan untuk mengembalikan konsep pemilihan umum yang mencerminkan demokrasi sebagaimana yang disepakati dalam Pancasila.

Setiap bangsa mempunyai suatu sistem nilai yang menjadi konsensus bersama. Begitu juga pada bangsa Indonesia. Sejak awal kemerdekaan, Indonesia telah sepakat bahwa Pancasila ditempatkan sebagai kesepakatan luhur yang final (modus vivendi). Pancasila merupakan satu kesatuan nilai yang saling terhubung antara sila satu dengan sila lainnya, yang harus digunakan sebagai pedoman untuk mengembangkan dan mencapai tujuan nasional. Untuk mencapai tujuan nasional tersebut, perlu dilakukan pembangunan di segala bidang (Suteki, 2011), termasuk pembangunan demokrasi.

Berkaitan dengan sistem nilai ini, Mochtar Kusumaatmadja mengemukakan, bahwa dalam esensinya, sistem nilai itu dapat dibedakan ke dalam nilai dasar (basevalues) sebagai landasan dan acuan untuk mencapai atau memperjuangkan sesuatu, dan nilai tujuan (goal-values) sebagai sesuatu yang harus dan layak untuk diperjuangkan atau diwujudkan. Sebagai sistem nilai, Pancasila merupakan "base values" dan sekaligus juga merupakan "goal-values" (Sidharta, 2012).

\section{Simpulan}

Konstitusi Indonesia telah mengatur bahwa kedaulatan berada di tangan rakyat dan dilaksanakan menurut UUD 1945. Dalam hal menjalankan kedaulatan, rakyat membutuhkan wakil-wakilnya agar kepentingan rakyat dapat berjalan sesuai kehendak rakyat. Wakil-wakil inilah dipilih melalui Pemilu. Oleh karena itu, Pemilu harus diselenggarakan sebagai perwujudan dari pemaknaan sila ke-empat Pancasila yang mengedepankan calon-calon wakil rakyat yang jujur, adil, bijaksana, sarat kehikmatan dalam pengambilan keputusan, dan meluhurkan rasa kekeluargaan dan gotong royong yang tampak kepada para generasi pilihan yang mencapai kriteria keterpilihan, yaitu kredibilitas, berintegritas, berdedikasi tinggi serta memiliki loyalitas kepada bangsa dan negara.

Mengembalikan iklim demokrasi di Indonesia berdasarkan Pancasila menjadi hal yang penting menjadi perhatian bangsa, khususnya oleh penyelenggara pemerintahan. Pemerintah dalam menjalankan demokrasi hendaknya konsisten dengan apa yang sudah disepakati dalam Pancasila. Oleh karena itu, pemilihan pemimpin juga harus sejalan dengan kesepakatan awal, yaitu melalui perwakilan, bukan melalui pemilu langsung. 


\section{DAFTAR PUSTAKA}

Al Hidayat, N. (2018). Pemilihan Presiden dan Wakil Presiden Langsung Dalam Demokrasi Pancasila di Indonesia. Jurnal Pancasila Dan Kewarganegaraan, 3(1), 3.

Asshiddiqie, J. (2013). Pengantar Ilmu Hukum Tata Negara. Jakarta: PT RajaGrafindo.

Azed, A. B. (1987). Sistem Pemilihan Umum di Indonesia. Jurnal Hukum Dan Pembangunan, 17(2), 170.

Bachtiar, F. R. (2014). Pemilu Indonesia: Kiblat Negara Demokrasi dari Berbagai Representasi. Jurnal Politik Profetik, 3(1), 2.

Firdaus, A. (2020). Money Politics dalam Pemilihan Umum oleh Badan Pengawasan Pemilihan Umum: Pengawasan Tindak Pidana Pemilu. Justiqa, 02(01), 62.

Hardiyanto dkk. (2016). Pemilihan Umum Kepala Daerah Periode 2015/2020 (Studi Politik Hukum Calon Tunggal). Varia Justicia, 12(1), 206.

Insiyah, S., Nugraha, X., \& Danmadiyah, S. (2019). Pemilihan Kepala Daerah oleh Dewan Perwakilan Rakyat Daerah: Sebuah Komparasi dengan Pemilihan secara Langsung oleh Rakyat. Supremasi Hukum: Jurnal Penelitian Hukum, 28(2), 172.

Ismatullah, D., \& Gatara, A. A. S. (2007). Ilmu Negara dalam Multi Perspektif: Kekuasaan, Masyarakat, Hukum dan Agama. Bandung: CV Pustaka Setia.

Juliardi, B. (2015). Pendidikan Kewarganegaraan untuk Perguruan Tinggi. Jakarta: PT. RajaGrafindo Persada.

Mulyono, G. P., \& Fatoni, R. (2019). Demokrasi Sebagai Wujud Nilai-Nilai Sila Keempat Pancasila Dalam Pemilihan Umum Daerah Di Indonesia.
Citizenship Jurnal Pancasila Dan Kewarganegaraan, 7(2), 98.

Nahuddin, Y. E. (2017). Pemilihan Umum Dalam Sistem Demokrasi Prespektif Sila Ke-4 Pancasila. Jurnal Cakrawala Hukum, 8(2), 247.

Nugraha, A., \& Mulyandari, A. (2016). Pilkada Langsung dan Pilkada Tidak Langsung dalam Perspektif Fikih Siyasah. Mazahib, XV(2), 210.

Pinilih, S. A. G., \& Hikmah, S. N. (2018). Aktualisasi Nilai-Nilai Pancasila Terhadap Hak Atas Kebebasan Beragama dan Beribadah di Indonesia. Masalah-Masalah Hukum, 47(1), 43.

Sanit, A. (2009). Politik dan Pemerintahan Indonesia. (A. Ramses M, Ed.). Jakarta: Masyarakat Ilmu Pemerintahan Indonesia.

Sarbaini. (2015). Demokratisasi dan Kebebasan Memilih Warga Negara dalam Pemilihan Umum. Inovatif: Jurnal Ilmu Hukum, VIII(1), 107.

Sidharta, B. A. (2012). Struktur Ilmu Hukum. In Refleksi dan Rekonstruksi Ilmu Hukum Indonesia (p. 63). Yogyakarta: Thafa Media.

Soerya, R. H. M. (2013). Pemilihan Kepala Daerah Dalam Demokrasi Electoral. Jurnal Masalah-Masalah Hukum, 43(3), 356.

Suteki, S. (2011). Legal Pluralisme: Pendekatan Baru dalam Cara Berhukum Berperspektif Ketimuran (Oriental). In Dialektika Epistemologis dan Praksis Hukum Progresif. Semarang: Satjipto Rahardjo Institute (SRI).

Wahyuningsih, S. E. (2014). Urgensi Pembaharuan Hukum Pidana Materiel Indonesia Berdasarkan Nilai-Nilai Ketuhanan Yang Maha Esa. Jurnal Pembaharuan Hukum, I(1), 17.

Wawan S., dkk. (2015). Tinjauan Yuridis Perbandingan Sistem Pilkada Langsung 
dan Tidak Langsung Berdasarkan Demokrasi Pancasila. Jurnal Dinamika Sosbud, 17(2), 306.

Yusdiyanto, Y. (2016). Makna Filosofis
Nilai-Nilai Sila Ke-Empat Pancasila Dalam Sistem Demokrasi Di Indonesia. Fiat Justisia Journal of Law, 10(2), 265. 